\title{
Correction to: Mercury Exposure: Protein Biomarkers of Mercury Exposure in Jaraqui Fish from the Amazon Region
}

José Cavalcante Souza Vieira $^{1} \cdot$ Camila Pereira Braga $^{1}$ (1) $\cdot$ Grasieli de Oliveira $^{1}$. Cilene do Carmo Federici Padilha ${ }^{1}$ • Paula Martin de Moraes ${ }^{1} \cdot$ Luiz Fabricio Zara $^{2}$. Aline de Lima Leite ${ }^{3}$. Marília Afonso Rabelo Buzalaf ${ }^{3}$. Pedro de Magalhães Padilha ${ }^{1}$

Published online: 2 November 2017

(C) Springer Science+Business Media, LLC 2017

Correction to: Biol Trace Elem Res (2017)

https://doi.org/10.1007/s12011-017-1129-5

The authors would like to correct the above referenced article.

In the affiliation section, Luiz Fabricio Zara's affiliation "Pontifical Catholic University of Goiás (PUC), Goiânia, GO, Brazil" was incorrect. The correct affiliation is College of Planaltina, UnB - University of Brasília, Distrito Federal, Brazil

The authors regret the oversight.

The online version of the original article can be found at https://doi.org/ 10.1007/s12011-017-1129-5

\footnotetext{
Camila Pereira Braga

braga_ca@ibb.unesp.br

1 Institute of Bioscience of Botucatu, São Paulo State University (UNESP), Rubião Júnior, Botucatu, São Paulo 18618-970, Brazil

2 College of Planaltina, UnB - University of Brasília, Distrito Federal, Brazil

3 Bauru Dental School, University of São Paulo-USP, Bauru, SP, Brazil
} 